\title{
The beta-carboline alkaloid harmine inhibits telomerase activity of MCF-7 cells by down-regulating hTERT mRNA expression accompanied by an accelerated senescent phenotype
}

The end replication problem, which occurs in normal somatic cells inducing replicative senescence, is solved in most of cancer cells by activating telomerase. The activity of telomerase is highly associated with carcinogenesis which makes the enzyme an attractive biomarker in cancer diagnosis and treatment. The indole alkaloid harmine has multiple pharmacological properties including DNA intercalation which can lead to frame shift mutations. In this study, harmine was applied to human breast cancer MCF-7 cells. Its activity towards telomerase was analyzed by utilizing the telomeric repeat amplification protocol (TRAP). Our data indicate that harmine exhibits a pronounced cytotoxicity and induces an anti-proliferation state in MCF-7 cells which is accompanied by a significant inhibition of telomerase activity and an induction of an accelerated senescence phenotype by overexpressing elements of the p53/p21 pathway. 
1 Lei Zhao ${ }^{1,2}$ and Michael Wink ${ }^{2 *}$

$2{ }^{1 .}$ Department of Molecular and Experimental Medicine, Scripps Research Institute, 10550 North

3 Torrey Pines Road, La Jolla, California 92037

$4{ }^{2 .}$ Institute of Pharmacy and Molecular Biotechnology, Heidelberg University, INF 364, 69120

5 Heidelberg, Germany

$6 *$ Corresponding author.

7 Prof. Dr. Michael Wink,

8 Institute of Pharmacy and Molecular Biotechnology, Heidelberg University, INF 364, 69120

9 Heidelberg, Germany

10 Tel +49-6221-544881

11 wink@uni-hd.de

\section{INTRODUCTION}

13 The end replication problem results in a continuous shortening of each end of a chromosome. In

14 most somatic cells the shortened fragments cannot be compensated. Cells stop dividing when

15 telomeres reach a critical length and replicative senescence is initiated consequently. However,

16 most cancer cells can conquer this obstacle, because their telomerase, a ribonucleoprotein that

17 replicates telomere sequences at each cell division, remains active. Telomerase is highly

18 associated with carcinogenesis. It is detectable in $85-90 \%$ of human cancers and over $70 \%$ of

19 immortalized human cell lines (Kim et al., 1994; Shay \& Wright, 1996a,b), whereas it is

20 undetectable in non-transformed somatic cells. Therefore, telomerase is an attractive target for the

21 development of anti-cancer drugs.

22 Telomerase is a cellular reverse transcriptase containing two components: A protein

23 element, telomerase reverse transcriptase (in human, hTERT) serving as catalytic subunit and an

24 RNA element, hTR, providing a template for telomere synthesis (Nakamura et al., 1997).

25 Recent evidence suggests that increased telomere dysfunction leads to a loss of

26 chromosome end protection and induces the senescence state. But senescence can also be induced

27 without continuous telomere shortening suggesting that telomere integrity is critical regardless of

28 telomere length. Tumour suppressor proteins such as p53 are required for the senescence arrest

29 (Liu \& Kulesz-Martin, 2001; Gorbunova et al., 2002; Gewirtz et al., 2008). 
Harmine, a naturally occurring $\beta$-carboline alkaloid, has long been used in folk medicine

31

in the Middle East and in Asia (Sourkes, 1999) and as a hallucinogenic drug (Wink \& van Wyk, 2008). It was first isolated from the seeds of Peganum harmala L. in 1874 (Budavari, 1989; Roberts \& Wink, 1998; Wink \& van Wyk, 2008; Wink et al., 1998b). Harmine has multiple pharmacological properties including antiplasmodial activity (Astulla et al., 2008), antimutagenic and antiplatelet properties (Im et al., 2009). In vitro studies demonstrate that the planar structure of harmine leads to DNA intercalation. Since DNA intercalation causes frame shift mutations, these alkaloids are known to be mutagenic, cytotoxic and antimicrobial (Roberts \& Wink, 1998; Wink, 2007). Burger and the colleagues had observed about decades ago that harmine could inhibit monoamine oxidase (Burger and Nara, 1965), through which way to regulate the metabolism of neurotransmitters (Kim et al. 1997; Wink et al., 1998). Recent data indicate that harmine and related alkaloids act as agonists at serotonin receptors (Wink et al., 1998; Glennon et al., 2000; Song et al., 2004). Harmine and other $\beta$-carboline alkaloids therefore exhibit hallucinogenic properties (Wink \& van Wyk, 2008).

Data obtained from cell viability assays indicate that harmine is a promising inhibitor of cell proliferation in a variety of cancer cell lines (Song et al., 2004). It blocks the cell cycle at G0/G1 phase (Hamsa and Kuttan, 2011) accompanied with a decrease of cyclin-dependent kinase activity (Song et al. 2002, 2004). DNA intercalation is also involved in the inhibition of cell division as it prevents the transcription of several genes and causes frame shift mutations. Previous findings indicate that telomeres are a also target of intercalating drugs (Shammas et al., 2003, 2004); they can induce very stable G-quadruplex structures which cannot be replicated by telomerase (Burge et al., 2006). Some known anticancer drugs exhibit DNA intercalation, such as isoquinoline, quinoline, and indole alkaloids (Wink et al., 1998; Wink, 2007).

Among these alkaloids, the simple indole alkaloid harmine was identified in our laboratory as a potent DNA intercalating and cytotoxic natural product (Rosenkranz et al., 2007). It has been reported that a few DNA-intercalating alkaloids, including berbamine (Ji et al., 2002), chelidonine (Noureini \& Wink, 2009) and 9-hydroxyellipticine (Sasaki et al., 1992) are inhibitors of telomerase activity. Because harmine is an intercalating and cytotoxic alkaloid a possible telomerase inhibition was evaluated in this research. The aim of this research was to examine the effects of harmine in human breast cancer MCF-7 cells and its possible interaction with telomerase. Anti-telomerase activity was analyzed using the telomeric repeat amplification protocol (TRAP). Harmine causes a pronounced cytotoxicity and induces an anti-proliferation 
62 state in MCF-7 cells. This process is accompanied by a significant inhibition of telomerase

63 activity and an induction of an accelerated senescence phenotype by over-expressing p53/p21.

\section{MATERIALS \& METHODS}

65 Chemicals

66 Harmine $\left(\mathrm{C}_{13} \mathrm{H}_{12} \mathrm{~N}_{2} \mathrm{O}\right.$; MW 212.25) was purchased from Sigma-Aldrich. The stock solution was

67 prepared in dimethyl sulfoxide (DMSO) with a concentration of $100 \mu \mathrm{M}$, which was stored at -20 $68{ }^{\circ} \mathrm{C}$.

69 Cell culture and harmine treatment

Human breast cancer cell line MCF-7 was kindly provided by Prof. Dr. S. Wölfl (IPMB, Heidelberg University). Cells were routinely cultured in Dulbeccos's Modified Eagle's Medium (DMEM, Invitrogen) supplemented with $2 \mathrm{mM}$ glutamine, $100 \mathrm{U} / \mathrm{ml}$ penicillin, $100 \mu \mathrm{g} / \mathrm{ml}$ streptomycin (Invitrogen, USA), and 10\% heat-inactivated fetal bovine serum. Cells were incubated at $37{ }^{\circ} \mathrm{C}$ in $5 \% \mathrm{CO}_{2}$ and $100 \%$ humidity. Twenty-four h after plating, cells were treated with harmine and incubated up to different time points depending on the experimental design. A DMSO control was included in each analysis.

Metabolic cell activity assay

Ten microliters of 3-[4,5-dimethylthiazol-2-yl]-2,5-diphenyl tetrazolium bromide (MTT) (5 $\mathrm{mg} / \mathrm{ml}$ ) prepared in phosphate-buffered saline buffer were added to each well after given time intervals; all plates were gently shaken by hands for several times and incubated at $37{ }^{\circ} \mathrm{C}$ for $3-4$ h. At the end of incubation, the solution with MTT was carefully removed and $100 \mu$ of lysis buffer (20\% SDS in 1:1 N,N'-dimethylformamide : water/ $2 \%$ acetic acid/ $2.5 \% \mathrm{HCl} 1 \mathrm{M})$ was added per well. Then the plates were placed on a shaker at low speed for $30 \mathrm{~min}$ at room temperature to ensure that the formazan formed was completely solubilized; it was quantified by measuring the OD value at $570 \mathrm{~nm}$ in a 96-well plate reader (Spectramax 384 plus, Molecular Devices).

\section{Telomerase activity assay}

88 Proteins were isolated from MCF-7 cells with CHAPS lysis buffer (10 mM Tris-HCl, pH 7.5; 1 $\mathrm{mM} \mathrm{MgCl} 2,1 \mathrm{mM}$ EDTA, 0.5\% CHAPS, and 10\% glycerol). All buffers and solutions were prepared with RNase-free water. Telomerase activities was determined with $0.5 \mu$ g protein extract using TRAP as described previously (Kim et al., 1994b). Briefly, the protein extract was firstly 
93 of CX primer (5' AATCCCATTCCCATTCCCATTCCC 3') the products were then subjected to

94 PCR-amplification at $94{ }^{\circ} \mathrm{C}$ for $30 \mathrm{sec}$, and at $60{ }^{\circ} \mathrm{C} 30 \mathrm{sec}$ for $29 \mathrm{cycles}$. The PCR products were

95 separated on a $12.5 \%$ polyacrylamide gel by PAGE. The gel was stained with SYBR green

96 (Amersham Biosciences) and directly visualized under a UV-transilluminator. A 36-bp internal

97 control was amplified to serve as a standard for the normalization of telomerase expression. The

98 intensity of all bands were photo scanned using ImageJ software (National Institutes of Health,

99 America), the relative telomerase activity (RTA) was determined by the formula (Betts and King 100 1999).

101

$(\mathrm{s}-\mathrm{b}) / \mathrm{ic}_{\mathrm{s}}$

102

103

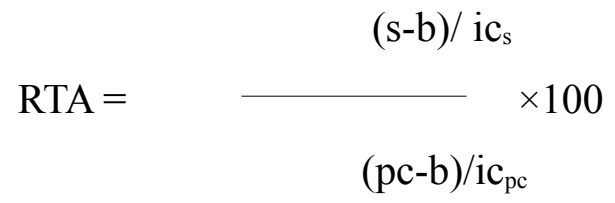

s: Intensity of sample pc: Intensity of positive control b: Intensity of background ic: Intensity of internal control

104 Values are expressed as \% of the control sample.

\section{Reverse transcription PCR of endogenous hTERT expression}

106 Total RNA was isolated from MCF-7 cells using RNeasy kit (Qiagen, Germany). One $\mu \mathrm{g}$ of total

107 RNA was reverse transcribed in a $20 \mu \mathrm{L}$ reaction volume using ImProm- $\mathrm{II}^{\mathrm{TM}}$ Reverse

108 Transcription System (Promega, Germany). A $1 \mu \mathrm{L}$ aliquot of cDNA was analyzed by PCR

109 amplifications. Global hTERT was amplified using the primer 5'-

110

CGGAAGAGTGTCTGGAGCAA-3' paired with 5'-GGATGAAGCGGAGTCTGGA-3';

111 variant-hTERT was amplified with the primer 5'-GCCTCAGCTGTACTTTGTCAA-3' paired with 5'-CGCAAACAGCTTGTTCTCCATGTC-3'. The thermocycling conditions for global

113 hTERT amplification were: $94{ }^{\circ} \mathrm{C} 2$ min followed by 33 cycles of $94{ }^{\circ} \mathrm{C}$ for $45 \mathrm{sec}, 60^{\circ} \mathrm{C}$ for 45

$114 \mathrm{sec}$, and $72{ }^{\circ} \mathrm{C}$ for $90 \mathrm{sec}$; for variant hTERT amplification, the thermocycling conditions were:

$11594{ }^{\circ} \mathrm{C}$ for $2 \mathrm{~min}$ followed by 35 cycles of $94{ }^{\circ} \mathrm{C}$ for $15 \mathrm{sec}, 60^{\circ} \mathrm{C}$ for $15 \mathrm{sec}$, and $72{ }^{\circ} \mathrm{C}$ for $30 \mathrm{sec}$.

116 The housekeeping gene $\beta$-actin was amplified with the primer 5'-CCTGGCACCCAGCACAAT-3'

117 paired with 5'-GGGCCGGACTCGTCATAC-3' under the same thermocycling conditions

118 described above with only 20 cycles. Amplified products (global hTERT: 145-bp; variant hTERT:

119 full length variant, 457-bp; $\alpha$ variant, 421-bp; and $\beta$ variant 275-bp; $\beta$-actin: 143-bp) were

120 separated by gel electrophoresis on a $\%$ agarose gel and visualized by ethidium bromide

121 staining.

\section{Semi-quantitative PCR analysis}


123 One microliter of cDNA was applied in $10 \mu \mathrm{L}$ PCR reaction in capillaries containing $1 \times \mathrm{SYBR}$

124 Green Master Mix (ABgene), $0.3 \mu \mathrm{M}$ of each primer. A non-template control was included as the

125 negative control. The PCR reaction was performed in LightCycler3 (Roche, Germany) with

126 initial 10 min denaturation at $95{ }^{\circ} \mathrm{C}$, then followed with 45 cycles: $95{ }^{\circ} \mathrm{C} 10 \mathrm{sec} ; 60{ }^{\circ} \mathrm{C} 10 \mathrm{sec}$. All

127 crossing point ( $\mathrm{cp}$ ) values were assessed by using REST software relative to the expression of $\beta$ -

128 actin. Primers which were used in Real-Time PCR are listed in Table 1.

$129 \boldsymbol{\beta}$-Galactosidase staining

130 MCF-7 cells were incubated with harmine for $48 \mathrm{~h}$ or $96 \mathrm{~h}$ before $\beta$-galactosidase activity was

131 determined. Then cells were washed twice in PBS and fixed in fixation solution containing $2 \%$

132 formaldehyde and $0.2 \%$ glutaraldehyde for $5 \mathrm{~min}$. The fixation solution was removed by washing

133 the cells twice in PBS, and then the staining solution was added. Cells were then incubated at 37

$134{ }^{\circ} \mathrm{C}$ in a $\mathrm{CO}_{2}$ free environment for $8 \mathrm{~h}$. The percentage of positively stained cells was determined

135 after counting three random fields of 100 cells each. Representative microscopic fields were

136 photographed under a 20x objective.

\section{Western blot analysis for p53 and p21waf-1 proteins}

138 MCF-7 cells were treated with $20 \mu \mathrm{M}$ harmine for multiple time points $(12,24$, 48, and $96 \mathrm{~h})$

139 prior to lysing the cells in Nonidet-P40 (NP40) lysis buffer (20 mM Tris, pH 7.4, $150 \mathrm{mM} \mathrm{NaCl,}$

1405 mM EDTA, 1\% NP40, and 10\% glycerol). The constitutive levels of p53 and p21 wafl were

141 assessed with respect to isogenic untreated MCF-7 cultures. Protein concentration was firstly

142 determined with standard Bradford assay (Bradford 1976), then a $25 \mu \mathrm{g}$ aliquot of the protein

143 extract was separated on a $12 \%$ of SDS-PAGE and transferred onto a PVDF membrane

144 (Millipore, Germany) by electroblotting. A standard blotting protocol was then performed using

145 p53 (DO1, Santa Cruz Biotech, Germany) and a p21 waf-1 monoclonal (BD Biosciences, Germany)

146 antibody followed by horseradish peroxidase-conjugated anti-mouse IgG (Dianova GmbH,

147 Germany). An enhanced chemiluminescent reaction (ECL Reagent, Amersham) was applied for

148 the detection.

149 RESULTS

150 Harmine is cytotoxic to MCF-7 cells in a dose- and time-dependent manner and induces

151 accelerated senescence

152 The cytotoxicity of harmine in MCF-7 cells is shown in Fig. 1. Cell viability at various time

153 points was determined by MTT assay. The results indicate that harmine arrests cell growth in a

154 dose- and time-dependent manner. Concentrations of 20 and $30 \mu \mathrm{M}$ harmine significantly 
155 reduced cell growth after 48 to $96 \mathrm{~h}$. Concentrations between 10 and $20 \mu \mathrm{M}$ did not influence

156 viability of MCF-7 cells within the first $24 \mathrm{~h}$, and were therefore used in the subsequent

157 experiments.

158 In the next step we tried to study whether senescent cells could be identified in response

159 to harmine treatment. In MCF-7 cells, harmine arrests cell proliferation and induces a senescence

160 morphology. $\beta$-Galactosidase activity, as a senescence marker, was detectable as early as $2 \mathrm{~d}$ after

161 treatment with harmine, and became intense and expressed in virtually every cell of the culture at

162 day 4 (Fig. 2). Cells, which were $\beta$-galactosidase positive, were larger in size or multinucleated

163 (indicated with arrows), both of which are morphological features indicative of a senescent state.

164 The SA- $\beta$-gal staining was not detected or barely detected in untreated control cells.

165 Telomerase activity

166 Telomerase activity of MCF-7 cells, treated with or without harmine, was evaluated as evidenced

167 by the TRAP assay. A decreased telomerase activity (Fig. 3A) was detected after the incubation of

168 the cells with $20 \mu \mathrm{M}$ harmine. Telomerase activity was inhibited by $81.87 \%$ after $96 \mathrm{~h}$ treatment

169 as compared to the untreated control (Fig. 3B). Treatment at a lower concentration, e.g., $10 \mu \mathrm{M}$,

170 did not show a significant reduction of telomerase activity.

171 Expression analysis of human TERT splicing variants by RT-PCR.

172 RT-PCR analysis was performed with a pair of primers which covers all hTERT transcripts. In

173 theory, four hTERT variants should be expected under the identical PCR conditions at the same

174 time (full length hTERT with $457 \mathrm{bp} ; \alpha$ variant with $421 \mathrm{bp} ; \beta$ variant with $275 \mathrm{bp}$ and $\alpha+\beta$

175 variant with 239 bp). However, in our investigation the $\alpha+\beta$ variant could not be detected (Fig.

176 4A). Treatment of the cells with $20 \mu \mathrm{M}$ harmine significantly down-regulated all hTERT subunits

177 in a time-dependent manner (Fig. 4B).

178 Expression analysis of human TERT

179 Human hTERT, p21, and CDK2 mRNA transcripts were examined by real time PCR. Data were

180 analyzed by Relative Expression Software Tool (REST2008). PCR efficiency was set as 2 as

181 indicated by the software and the housekeeping gene $\beta$-actin was regarded as a control. A

182 significant up-regulation of p21 mRNA was detected as early as $12 \mathrm{~h}$ after harmine treatment.

183 The mRNA concentration was 3.9 fold higher than that of the untreated control, and the up-

184 regulation became 6.5 fold with respect to the control after $96 \mathrm{~h}$ (Fig. 5). Within the first $24 \mathrm{~h}$ of

185 treatment, no alteration on of hTERT and CDK2 mRNA expression was detected, while an

186 extended treatment up to $48 \mathrm{~h}$ showed that a significant down-regulation was observed for these

187 two genes. 
189 We had shown before that harmine arrested MCF-7 cell growth and induced senescence (Fig. 1 \& 190 2). In order to define the mechanism of harmine-induced cell arrest a serial of immunoblot 191 analyses were performed (Fig. 6A). MCF-7 cells were cultured with harmine in a final 192 concentration of $20 \mu \mathrm{M}$ and cell samples were collected at different time points $(24,48$, and 96 $193 \mathrm{~h})$. An enhanced expression of the phosphorylated $\mathrm{H}_{2} \mathrm{AX}\left(\gamma \mathrm{H}_{2} \mathrm{AX}\right)$ protein was detected after 194 harmine treatment (Fig 6B). An overexpressed p53 protein was identified by immunoblot analysis 195 as early as $24 \mathrm{~h}$ accompanied by an increased p21 protein. c-Myc is a known transcriptional 196 enhancer of hTERT expression. In our investigation, c-Myc was apparently down-regulated (Fig. 197 6B). Compared with the changes in other genes, the decrease of c-Myc was more moderate in 198 response to the treatment with harmine.

\section{DISCUSSION}

200 The indole alkaloid harmine exhibits multiple pharmacological properties in vivo and in vitro 201 (Wink \& van Wyk, 2008; Wink \& Schimmer, 2010). Among other effects, harmine significantly 202 arrests cell proliferation and induces cell death in a number of tumour cell lines. A dose- and 203 time- dependent cytotoxicity of harmine could be confirmed in our experiments with MCF-7 cells 204 (Fig. 1).

205 Cytotoxicity can result from an adverse interaction of harmine and other alkaloids with 206 one or more important targets present in a cell including DNA, RNA, or associated enzymes 207 (Roberts \& Wink, 1998; Wink \& van Wyk, 2008; Wink, 2007). Harmine is known to intercalate 208 DNA and through this it can cause mutations and DNA damage (Wink et al., 1998a; Wink \& 209 Schimmer, 2010). Through these interactions cell proliferation can be interrupted or cell death 210 induced (Lansiaux et al., 2002; Möller et al., 2007; Wink, 2007). In addition, the inhibition of 211 cycline-dependent kinases such as CDK2 and CDK5 (Song et al., 2002) might also contribute to

212 the cytotoxicity of harmine. Furthermore, it has been shown that harmine can repress cytochrome 213 P450 activity (Tweedie et al., 1988) and selectively inhibit DNA topoisomerase (Funayama et al., 214 1996).

215 Another mechanism for cytotoxicity of alkaloids might involve the intercalation of 216 telomeres and the inhibition of telomerase. Several DNA-intercalating alkaloids, including 217 berbamine (Ji et al., 2002), chelidonine (Noureini \& Wink, 2009) and 9-hydroxyellipticine 218 (Sasaki et al., 1992) could significantly inhibit telomerase activity which could lead to the 
219 interruption of the genomic stability as well as cell growth arrest (Shay \& Bacchetti, 1997).

220 Because harmine is an intercalating alkaloid a possible telomerase inhibition was evaluated in

221 this research. Indeed, as shown in our investigation, harmine induces a remarkable reduction of

222 telomerase activity in MCF-7 cells as measured by TRAP (a PCR-based assay to detect

223 telomerase activity) (Fig. 3). Harmine also triggers a significant inhibition of telomerase activity

224 in Hela cells (unpublished result), the concentrations applied in both cell lines were very similar

225 (20 $\mu \mathrm{M}$ in MCF-7 cells, $30 \mu \mathrm{M}$ in HeLa cells). Under our experimental condition, we did not find

226 the same senescent phenotype with HeLa cells. Also no down-regulation could be detected on

227 hTERT mRNA expression although telomerase activity was significantly inhibited after harmine

228 treatment. The mTOR pathway might be involved which needs to be further investigated. The

229 regulation of telomerase activity involves various signalling pathways (Shay and Wright,

230 1996a,b). It is commonly accepted that the expression of hTERT is critical for telomerase activity

231 (Meyerson et al., 1997; Nakamura et al., 1997; Bodnar et al., 1998). The transcription of hTERT

232 mRNA was significantly down-regulated in response to harmine treatment (Fig. $4 \& 5$ ). The

233 down-regulation became apparent about $24 \mathrm{~h}$ earlier than the reduction of telomerase activity

234 (TRAP assay) whereas no decrease in telomerase activity could be seen at the same condition.

235 Such an observation coincides with the report that telomerase activity has a half-life longer than

$23624 \mathrm{~h}$ in almost all cell lines (Holt et al., 1997) whereas the half-life of the hTERT mRNA is about

$2372 \mathrm{~h}$ (Xu et al. 1999). Our hypothesis is harmine does not induce a direct inhibition on telomerase

238 activity in MCF-7 cells but through down-regulating hTERT at transcriptional level.

239 Another factor could be c-Myc which plays an important role in the transcriptional

240 regulation of hTERT (Wu et al., 1999; Kyo et al., 2000). Overexpressed c-Myc protein leads to a

241 remarkable E-box dependent increase in the hTERT promoter activity. Moreover, c-Myc could

242 induce the expression of endogenous hTERT mRNA and telomerase activity in normal human

243 cells (Wang et al. 1998; Greenberg et al. 1999). In our experiments, a time-dependent down-

244 regulation of cMyc was observed (Fig. 6) which might be correlated with the down-regulation of

245 hTERT (Fig. 4).

246 The tumor suppressor protein p53 is a nuclear transcription factor that accumulates in

247 response to cellular stress, including DNA damage and oncogene activation (Wink, 2007). P53

248 protein is a critical determinant of the cell fate following certain types of DNA damage (Clarke et

249 al., 1993; Liu \& Kulesz-Martin, 2001). DNA damage triggers transcriptional transactivation of

250 p53 target genes such as p21, leading to cell cycle arrest, senescence and/or apoptosis (Levine,

251 1997; Farnebo et al., 2010). P53 is essential for both senescence and apoptosis pathways, 
252 specifically, in cell cycle arrest at $\mathrm{G}_{1}$ phase; p53 enhances p21 transcription, which in turn inhibits 253 CDK activity. As reported, overexpressed wild-type p53 could inhibit telomerase activity via 254 down-regulating hTERT transcription (Gollahon et al., 1998; Kusumoto et al., 1999). However, 255 such a reduction cannot be directly achieved by p53 because the binding site between p53 and the 256 hTERT promoter is missing (Gualberto and Baldwin, 1995; Bargonetti et al., 1997; Kyo et al., 257 2000).

In our study, p53 was overexpressed after harmine exposure (Fig. 6); an induction could 259 be detected as early as $12 \mathrm{~h}$ after treatment. This enhancement was accompanied by an increase 260 of mRNA level as well as on protein level of p21 (Fig. $5 \&$ 6). The question arises as to whether 261 the inhibition of hTERT is a consequence of overexpressed p53 or harmine-induced cell cycle 262 arrest. Harmine is able to interrupt DNA replication in vivo (Boeira et al., 2001; Moura et al., 263 2007; Sasaki et al., 1992) and in vitro (Wink, 2007). Other studies have found that harmine 264 induces chromosome aberrations and produces DNA breakage in cultured mammalian cells 265 (Boeira et al., 2001). Moreover, harmine can inhibit topoisomerase I (Cao et al., 2005; Wink et 266 al., 1998), therefore blocking an important enzyme which can repair DNA damage and fix mutations (Sasaki et al., 1992; Wang, 1998). The accumulation of phosphorylated $\mathrm{H}_{2} \mathrm{AX}\left(\gamma \mathrm{H}_{2} \mathrm{AX}\right)$ is an early sign of genomic events reflecting induction of double strands breaks (Tanaka et al. , 2007; Albino et al., 2004). In this study, an increase of $\gamma \mathrm{H}_{2} \mathrm{AX}$ was detected at $24 \mathrm{~h}$ after the treatment of harmine. Our hypothesis is that intercalating harmine induces a general timedependent DNA damage response. Instead of triggering apoptosis, such damage apparently initiates an accelerated senescence in MCF cells (Fig. 2). Similar results were obtained in other studies, in which MCF-7 cells failed to undergo apoptotic cell death but underwent accelerated senescence after the exposure of ionizing radiation and adriamycin (Elmore et al., 2002a; Jones et al., 2005). On the other hand, when p53 protein was diminished by infection with HPV-E6 oncogene, MCF-7-E6 cells entered delayed programmed cell death (Elmore et al., 2002b). A number of studies have demonstrated that replicative senescence induced by telomere shortening and DNA damage-induced senescence leads to a very similar cell morphology (Oh et al., 2001; Gorbunova et al., 2002; Gewirtz et al., 2008). Both events involve the participation of p53, the mechanisms however, remain unclear. progression by transactivating $\mathrm{p} 21$. Alternatively, the overexpressed p53 could directly inhibit 
284 hTERT transcription. The inhibited telomerase could then facilitate cell growth arrest in MCF-7

285 cells, and directs damaged cells into accelerated senescence and not into apoptotic pathway.

\section{ACKNOWLEDGEMENTS}

287 We thank Holger Schäfer for helpful discussions.

\section{REFERENCES}

289 Albino AP, Huang X, Jorgensen E, Yang J, Gietl D, Traganos F, Darzynkiewicz Z. 2004.

290

291

292

293

Induction of $\mathrm{H} 2 \mathrm{AX}$ phosphorylation in pulmonary cells by tobacco smoke: a new assay for carcinogens. Cell Cycle 3: 1062-1068.

Astulla A, Zaima K, Matsuno Y, Hirasawa Y, Ekasari W, Widyawaruyanti A, Zaini NC, Morita H. 2008. Alkaloids from the seeds of Peganum harmala showing antiplasmodial and vasorelaxant activities. Journal Natural Medicines 62: 470-472.

Bargonetti J, Chicas A, White D, Prives C. 1997. p53 represses Sp1 DNA binding and HIV-LTR directed transcription. Cell Molecular Biology 43: 935-949.

Betts DH, King WA, 1999. Telomerase activity and telomere detection during early bovine development. Developmental Genetics 254: 397-403.

Bodnar AG, Ouellette M, Frolkis M, Holt SE, Chiu CP, Morin GB, Harley CB, Shay JW, Lichtsteiner S, Wright WE. 1998. Extension of life-span by introduction of telomerase into normal human cells. Science 279: 349-352.

Boeira JM, Erdtmann B, Henriques J 2001. Genotoxic effects of the alkaloids harman and harmine assessed by comet assay and chromosome aberration test in mammalian cells in vitro. Pharmacology and Toxicology 896: 287-294.

Bradford MM. 1976. A rapid and sensitive method for the quantitation of microgram quantities of protein utilizing the principle of protein-dye binding. Analytical Biochemistry 72: 248254.

Budavari S. 1989. The Merck Index Merck \& Co.

Burger A, Nara S. 1965. In vitro inhibition studies with homogeneous monoamine oxidases Journal Medicinal Chemistry 86: 859-862.

311 Burge S, Parkinson GN, Hazel P, Todd AK, Neidle S. 2006. Quadruplex DNA: Sequence, topology and structure. Nucleic Acids Research 34: 5402-5415. 
313 Cao R, Peng W, Chen H, Ma Y, Liu X, Hou X, Guan H, Xu A. 2005. DNA binding properties of 314 9-substituted harmine derivatives. Biochemical Biophysical Research Communications $315 \quad 3383: 1557-1563$.

316 Clarke AR, Purdie CA, Harrison DJ, Morris RG, Bird CC, Hooper ML, Wyllie AH. 1993.

317 Thymocyte apoptosis induced by p53-dependent and independent pathways. Nature $318 \quad 362: 849-852$.

319 Elmore LW, Rehder CW, Di X, McChesney PA, Jackson-Cook CK, Gewirtz DA, Holt SE. 2002. 320 Adriamycin-induced senescence in breast tumor cells involves functional p53 and 321 telomere dysfunction. Journal Biological Chemistry 277: 35509-35515.

322 Farnebo M, Bykov VJ, Wiman KG. 2010. The p53 tumor suppressor: a master regulator of 323 Research Communications 3961: 85-89.

Funayama Y, Nishio K, Wakabayashi K, Nagao M, Shimoi K, Ohira T, Hasegawa S, Saijo N. 1996. Effects of beta- and gamma-carboline derivatives of DNA topoisomerase activities. Mutation Research 349: 183-191.

Gewirtz DA, Holt SE, Elmore LW. 2008. Accelerated senescence: an emerging role in tumor cell response to chemotherapy and radiation. Biochemical Pharmacology 768: 947-957.

Glennon RA, Dukat M, Grella B, Hong S, Costantino L, Teitler M, Smith C Egan C, Davis K, Mattson MV. 2000. Binding of beta-carbolines and related agents at serotonin 5-HT2 and 5-HT1A dopamine D2 and benzodiazepine receptors. Drug Alcohol Dependance 602: 121-132.

Gollahon LS, Kraus E, Wu TA, Yim SO, Strong LC, Shay JW, Tainsky MA. 1998. Telomerase activity during spontaneous immortalization of Li-Fraumeni syndrome skin fibroblasts. Oncogene 176: 709-717.

Gorbunova V, Seluanov A, Pereira-Smith OM. 2002. Expression of human telomerase hTERT does not prevent stress-induced senescence in normal human fibroblasts but protects the cells from stress-induced apoptosis and necrosis. Journal Biological Chemistry 277: 38540-38549.

Greenberg A, O'Hagan RC, Deng H, Xiao Q, Hann SR, Adams RR, Lichtsteiner S, Chin L, Morin GB, DePinho RA. 1999. Telomerase reverse transcriptase gene is a direct target of c-Myc but is not functionally equivalent in cellular transformation. Oncogene 185: 1219-1226. 
344 Gualberto A, Baldwin AS. 1995. p53 and Sp1 interact and cooperate in the tumor necrosis factorinduced transcriptional activation of the HIV-1 long terminal repeat. Journal Biological Chemistry 270: 19680-19683.

347 Hamsa TP, Kuttan G. 2011. Harmine activates intrinsic and extrinsic pathways of apoptosis in 348 B16F-10 melanoma. Chinese Medicine 6:11.

349 Holt SE, Aisner DL, Shay JW, Wright WE. 1997. Lack of cell cycle regulation of telomerase activity in human cells. Proceedings of the National Academy of Sciiences, U. S. A, 94:10687-10692.

352 353

354 355 356 357 358 359 360
Im JH, Jin YR, Lee JJ, Yu JY, Han XH, Im SH, Hong JT, Yoo HS, Pyo MY, Yun YP. 2009. Antiplatelet activity of beta-carboline alkaloids from Perganum harmala: a possible mechanism through inhibiting PLCgamma2 phosphorylation. Vascular Pharmacology 505: $147-152$.

Ji ZN, Ye WC, Liu GQ, Huang Y. 2002. Inhibition of telomerase activity and bcl-2 expression in berbamine-induced apoptosis in HL-60 cells. Planta Medica 68: 596-600.

Jones KR, Elmore LW, Jackson-Cook C, Demasters G, Povirk LF, Holt SE, Gewirtz DA. 2005. p53-Dependent accelerated senescence induced by ionizing radiation in breast tumour cells. International Journal Radiation Biology 816: 445-458.

Kim H, Sablin SO, Ramsay RR. 1997. Inhibition of monoamine oxidase A by beta-carboline derivatives. Archives of Biochemistry and Biophysics 337: 137-142.

Kim NW, Piatyszek MA, Prowse KR, Harley CB, West MD, Ho PL, Coviello GM, Wright WE, Weinrich SL, Shay JW. 1994. Specific association of human telomerase activity with immortal cells and cancer. Science 266: 2011-2015.

Kusumoto M, Ogawa T, Mizumoto K, Ueno H, Niiyama H, Sato N, Nakamura M, Tanaka M. 1999. Adenovirus-mediated p53 gene transduction inhibits telomerase activity independent of its effects on cell cycle arrest and apoptosis in human pancreatic cancer cells. Clinical Cancer Research 58: 2140-2147.

Kyo S, Takakura M, Taira T, Kanaya T, Itoh H, Yutsudo M, Ariga H, Inoue M. 2000. Sp1 cooperates with c-Myc to activate transcription of the human telomerase reverse transcriptase gene hTERT. Nucleic Acids Research 283: 669-677. 
373 Lansiaux A, Bailly C, Houssier C, Colson P, De Pauw-Gillet MC, Frederich M, Tits M, Angenot

374

375

376

377

378

379

380

381

382

383

384

385

386

387

388

389

390

391

392

393

394

395

396

397

398

399

400

401

402

403

L. 2002. Apoptosis of HL-60 leukemia cells induced by the bisindole alkaloids sungucine and isosungucine from Strychnos icaja. Planta Medica 687: 591-595.

Levine AJ. 1997. p53 the cellular gatekeeper for growth and division. Cell 883: 323-331.

Liu YG, Kulesz-Martin M. 2001. p53 protein at the hub of cellular DNA damage response pathways through sequence-specific and non-sequence-specific DNA binding. Carcinogenesis 226: 851-860.

Meyerson M, Counter CM, Eaton EN, Ellisen LW, Steiner P, Caddle SD, Ziaugra L, Beijersbergen RL, Davidoff MJ, Liu Q, Bacchetti S, Haber DA, Weinberg RA. 1997. hEST2 the putative human telomerase catalytic subunit gene is up-regulated in tumor cells and during immortalization. Cell 904: 785-795.

Möller M, Herzer K, Wenger T, Herr I, Wink M. 2007. The alkaloid emetine as a promising agent for the induction and enhancement of drug-induced apoptosis in leukemia cells. Oncology Reports 183: 737-744.

Moura DJ, Richter MF, Boeira JM, Pegas Henriques JA, Saffi J. 2007. Antioxidant properties of beta-carboline alkaloids are related to their antimutagenic and antigenotoxic activities. Mutagenesis 224: 293-302.

Nakamura TM, Morin GB, Chapman KB, Weinrich SL, Andrews WH, Lingner J, Harley CB, Cech TR. 1997. Telomerase catalytic subunit homologs from fission yeast and human. Science 277: 955-959.

Noureini SK, Wink M. 2009. Transcriptional down regulation of hTERT and senescence induction in HepG2 cells by chelidonine. World Journal of Gastroenterology 15:36033610.

Oh CW, Bump EA, Kim JS, Janigro D, Mayberg MR. 2001. Induction of a senescence-like phenotype in bovine aortic endothelial cells by ionizing radiation. Radiation Research 156: $232-240$.

Roberts MF, Wink M. 1998. Alkaloids: Biochemistry Ecological Functions and Medical Applications. Plenum Press, New York.

Rosenkranz V, Wink M. 2007. Induction of apoptosis by alkaloids, non-protein amino acids, and cardiac glycosides in Human promyelotic HL-60 cells. Zeitschrift für Naturforschung 62c: $458-466$ 
404 Sasaki YF, Yamada H, Shimoi K, Kinae N, Tomita I, Matsumura H, Ohta T, Shirasu Y. 1992.

405 Enhancing effects of heterocyclic amines and beta-carbolines on the induction of

406 chromosome aberrations in cultured mammalian cells. Mutation Research 269: 79-95.

407 Shammas MA, Shmookler Reis RJ, Akiyama M, Koley H, Chauhan D, Hideshima T, Goyal R K,

408 Hurley LH, Anderson KC, Munshi NC. 2003). Telomerase inhibition and cell growth

409 arrest by G-quadruplex interactive agent in multiple myeloma. Molecular Cancer

$410 \quad$ Therapies 2:825-833.

411 Shammas MA, Shmookler Reis RJ, Li C, Koley H, Hurley LH, Anderson KC, Munshi NC. 2004.

412 Telomerase inhibition and cell growth arrest after telomestatin treatment in multiple

413 myeloma. Clinical Cancer Research 10: 770-776.

414

415

416

417

418

419

420

421

422

423

424

425

426

427

428

429

430

431

432

Shay JW, Bacchetti S. 1997. A survey of telomerase activity in human cancer. European Journal of Cancer 33: 787-791.

Shay JW, Wright WE. 1996a. Telomerase activity in human cancer. Current Opinions Oncology 8: 66-71.

Shay JW, Wright WE. 1996b. The reactivation of telomerase activity in cancer progression. Trends in Genetics 12: 129-131.

Song Y, Kesuma D, Wang J, Deng Y, Duan J, Wang JH, Qi RZ. 2004. Specific inhibition of cyclin-dependent kinases and cell proliferation by harmine. Biochemical Biophysical Research Communications 317: 128-132.

Song Y, Wang J, Teng SF, Kesuma D, Deng Y, Duan J, Wang JH, Qi RZ, Sim MM. 2002. Betacarbolines as specific inhibitors of cyclin-dependent kinases. Bioorganical Medicinal Chemistry Letters 12: 1129-1132.

Sourkes TL. 1999. Rational hope in the early treatment of Parkinson's disease. Canadian Journal of Physiology and Pharmacology 77:375-382.

Tanaka T, Huang X, Jorgensen E, Gietl D, Traganos F, Darzynkiewicz Z, Albino AP. 2007. ATM activation accompanies histone $\mathrm{H} 2 \mathrm{AX}$ phosphorylation in A549 cells upon exposure to tobacco smoke. BMC Cell Biol 8: 26.

Tweedie DJ, Prough RA, Burke MD. 1988. Effects of induction on the metabolism and cytochrome P-450 binding of harman and other beta-carbolines. Xenobiotica 18: 785-796. 
433 Wang J, Xie LY, Allan S, Beach D, Hannon GJ. 1998. Myc activates telomerase. Genes 434 Development 12: 1769-1774.

435 Wang J.1998. Moving one DNA double helix through another by a type II DNA topoisomerase: 436 the story of a simple molecular machine. Quarterly Review Biophysics 31: 107-144.

437 Wink M. 2007. Molecular modes of action of cytotoxic alkaloids: from DNA intercalation 438 spindle poisoning topoisomerase inhibition to apoptosis and multiple drug resistance $439 \quad$ Alkaloids 64: 1-47.

440 Wink M, Schimmer O. 2010. Molecular modes of action of defensive secondary metabolites. In 441 Wink, M. (Ed.); Functions and Biotechnology of plant secondary metabolites, Wiley$442 \quad$ Blackwell, Annual Plant Reviews 39, 21-161, 2010

443 Wink M, Schmeller T, Latz-Bruening B. 1998. Modes of action of allelochemical alkaloids: 444 interaction with neuroreceptors DNA and other molecular targets. Journal of Chemical 445 Ecology 24: 1881-1937.

446 Wink M, van Wyk, BE. 2008. Mind-altering \& Poisons Plants of the World Timber Press 447 Wu KJ, Grandori C, Amacker M, Simon-Vermot N, Polack A, Lingner J, Dalla-Favera R. 1999. 448 Direct activation of TERT transcription by c-MYC. Nature Genetics 21: 220-224. 449 Xu D, Gruber A, Bjorkholm M, Peterson C, Pisa P. 1999. Suppression of telomerase reverse 450 transcriptase (hTERT) expression in differentiated HL-60 cells: regulatory mechanisms. 451 British Journal of Cancer 80:1156-1161. 
453 Figure 1 Cytotoxicity of harmine in MCF-7 cells. MCF-7 cells were incubated with harmine at 454 different concentrations $(0 \mu \mathrm{M}, 10 \mu \mathrm{M}, 20 \mu \mathrm{M}$ and $30 \mu \mathrm{M})$ and multiple time periods $(24 \mathrm{~h}, 48 \mathrm{~h}$, $45572 \mathrm{~h}$ and $96 \mathrm{~h}$ ). Cell metabolic activity was determined by MTT assay. Viability of vehicle-treated 456 samples was set 100\%: 24 h, white bars; 48 h, black bars; 72 h, hatched bars; 96 h, grey bars. 457 Results are derived from two independent experiments performed in quadruplicate (mean $\pm \mathrm{SD}$ ).

458 Figure 2 Harmine-induced senescence: SA- $\beta$-gal staining image of MCF-7 cells after 459 harmine treatment. MCF-7 cells were firstly treated with $20 \mu \mathrm{M}$ harmine for $48 \mathrm{~h}$ and $96 \mathrm{~h}$, 460 respectively. At the end of treatment, SA- $\beta$-gal staining was investigated following a standard 461 protocol. All images were taken at $10 \times$ magnification. Percentage of $\beta$-gal positive cells were 462 quantified by ImageJ software. Graph established from two independent areas (mean \pm S.D). $p$ 463 values indicate the significant difference in positive $\beta$-gal staining for the sample treated with 464 harmine with respect to the vehicle treated controls. Unpaired $t$ test: ${ }^{*} p \leq 0.05 ;{ }^{* * *} p \leq 0.001$.

465 Figure 3 Effect of harmine on telomerase activity in MCF-7 cells.

466 (A) MCF-7 cells were incubated with harmine at two concentrations (10 $\mu \mathrm{M}$ and $20 \mu \mathrm{M})$ for $46724 \mathrm{~h}, 48 \mathrm{~h}, 72 \mathrm{~h}$ and $96 \mathrm{~h}$. At the end of incubation, telomerase activity was evaluated by 468 applying TRAP assay; the TRAP products were then separated on a 12\% PAGE gel and their 469 intensity (all bands) was quantified by using Image J software and values were plotted in (B):

$470 \mathrm{Ctr}$, vehicle control, black bar; cells treated with $10 \mu \mathrm{M}$ of harmine, white bars; cells treated 471 with $20 \mu \mathrm{M}$ of harmine, dotted bars. Results derived from two independent experiments 472 (mean \pm S.D). $p$ values indicate the significant changes in relative telomerase activity for the 473 sample treated with harmine with respect to the vehicle treated controls. Unpaired $t$ test: ${ }^{*} p$ $474<0.05 ; * * p \leq 0.01$.

475 Figure 4 Harmine inhibits telomerase expression in MCF-7 cells in a dose- and time476 dependent manner. (A) MCF-7 cells were incubated with harmine at final concentration of 10 $477 \mu \mathrm{M}$ and $20 \mu \mathrm{M}$, respectively, then total RNA was isolated and analyzed by using RT-PCR; (B) 
$478 \mathrm{MCF}-7$ cells were incubated with harmine at a final concentration of $20 \mu \mathrm{M}$ for $48 \mathrm{~h}$ or $96 \mathrm{~h}$, 479 respectively, then total RNA was isolated and analyzed by RT-PCR.

480 Figure 5 mRNA levels of hTERT, p21, and CDK2 in response to harmine treatment. MCF-

4817 cells were exposed to harmine at a final concentration of $20 \mu \mathrm{M}$ for $12 \mathrm{~h}, 24 \mathrm{~h}, 48 \mathrm{~h}$ and $96 \mathrm{~h}$, 482 then mRNA expression of each target gene was analyzed by real time PCR: hTERT, white bars; 483 p21, black bars; CDK2, hatched bars. Results are representative of two independent 484 experiments in triplicate (mean $\pm \mathrm{SD}$ ). $p$ values measure significant changes in mRNA 485 expression for the target gene treated with harmine with respect to the vehicle treated controls. 486 Unpaired $t$ test: $* p>0.05 ; * * p \leq 0.01 ; * * * \leq 0.001$.

487 Figure 6 Harmine induces a general DNA damage response by over-expressing p53/p21 and $488 \mathrm{H}_{2} \mathrm{AX}$. (A) MCF-7 cells were incubated with harmine at $20 \mu \mathrm{M}$ for $24 \mathrm{~h}, 48 \mathrm{~h}$ and $96 \mathrm{~h}$, then 25 $489 \mu \mathrm{g}$ of total protein extracted from cells after treatment of harmine or vehicle only was separated 490 by PAGE and analyzed by western blotting; (B) the changes in protein level after the treatment 491 were calculated with respect to vehicle controls (100\%): p21, black bars; p53, white bars; $492 \gamma \mathrm{H}_{2} \mathrm{AX}$, grey bars; c-Myc, hatched bars. 


\section{Table 1 (on next page)}

Table 1 Primers for RT-PCR 
1 Table 1 Primers for RT-PCR

\begin{tabular}{|l|l|}
\hline Gene & primer sequence (5'-3') \\
\hline$\beta-$ actin-f & CCTGGCACCCAGCACAAT \\
$\beta-$ actin-r & GGGCCGGACTCGTCATAC \\
\hline $2007 h$ TERT-f & ACGGCGACATGGAGAACAA \\
$2007 h T E R T-r$ & CACTGTCTTCCGCAAGTTCAC \\
\hline p21-f & TTTCTCTCGGCTCCCCATGT \\
p21-r & GCTGTATATTCAGCATTGTGGG \\
\hline Cdk2-f & CCTCCTGGGCTGCAAATA \\
Cdk2-r & CAGAATCTCCAGGGAATAGGG \\
\hline p53-f & TGCGTGTGGAGTATTTGGATG \\
p53-r & TGGTACAGTCAGAGCCAACCAG \\
\hline
\end{tabular}




\section{Figure 1}

Cytotoxicity of harmine in MCF-7 cells

MCF-7 cells were incubated with harmine at different concentrations $(0 \mu \mathrm{M}, 10 \mu \mathrm{M}, 20 \mu \mathrm{M}$ and $30 \mu \mathrm{M})$ and multiple time periods (24 h, $48 \mathrm{~h}, 72 \mathrm{~h}$ and $96 \mathrm{~h}$ ). Cell metabolic activity was determined by MTT assay. Viability of vehicle-treated samples was set $100 \%$ : $24 \mathrm{~h}$, white bars; 48 h, black bars; 72 h, hatched bars; 96 h, grey bars. Results are derived from two independent experiments performed in quadruplicate (mean $\pm S D$ ).

$\square$ harmine+/24 h $\square$ harmine+/72 h

$\square$ harmine+/48 h $\square$ harmine+/96 h

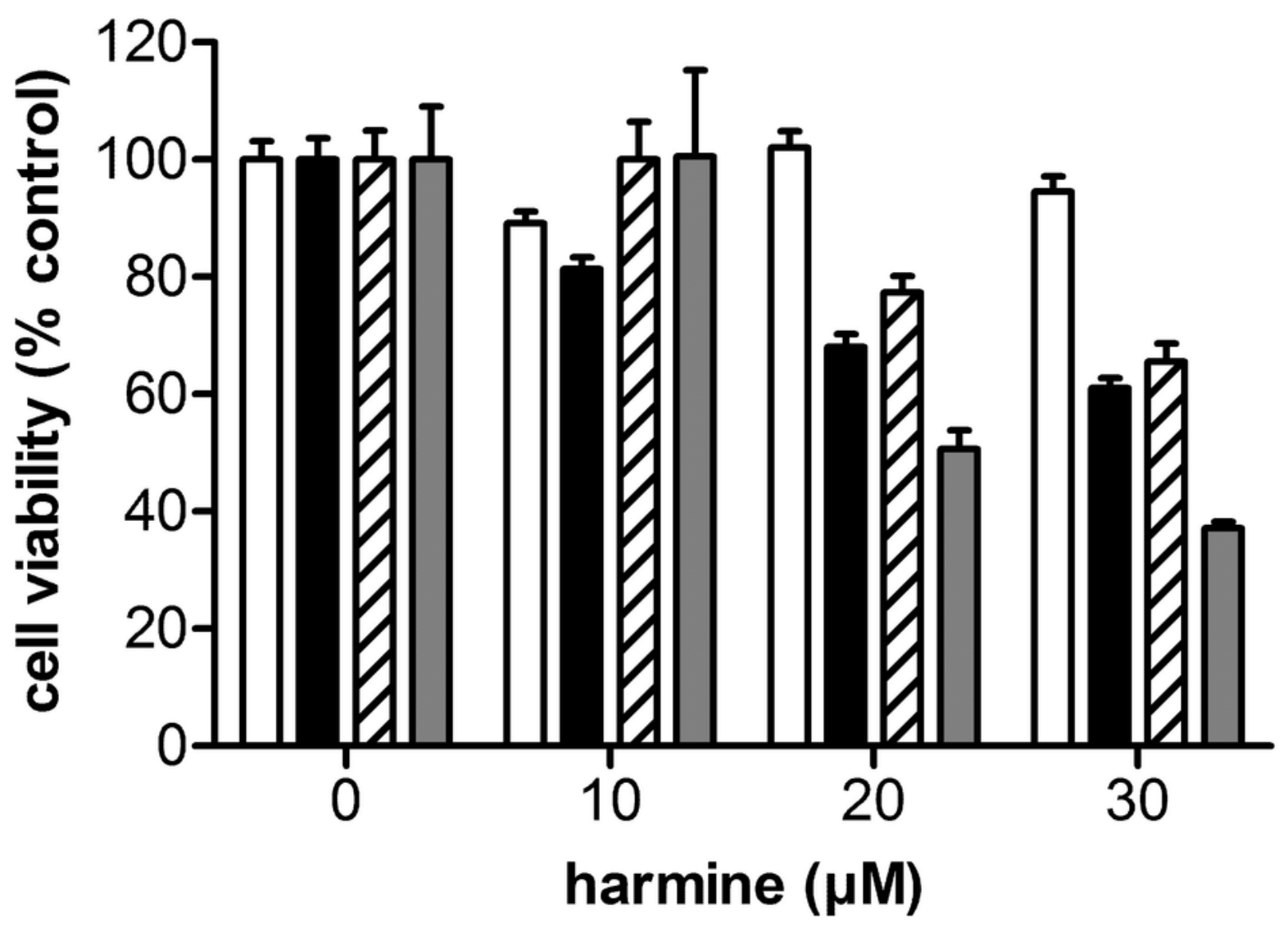




\section{Figure 2}

Harmine-induced senescence: SA- $\beta$ gal staining image of MCF-7 cells after harmine treatment.

MCF-7 cells were firstly treated with $20 \mu \mathrm{M}$ harmine for $48 \mathrm{~h}$ and $96 \mathrm{~h}$, respectively. At the end of treatment, SA- $\beta$ gal staining was investigated following a standard protocol. All images were taken at $10 \times$ magnification. Percentage of $\beta$ gal positive cells were quantified by ImageJ software. Graph established from two independent areas (mean \pm S.D). p values indicate the significant difference in positive $\beta$ gal staining for the sample treated with harmine with respect to the vehicle treated controls. Unpaired t test: ${ }^{*} p \leq 0.05$; ${ }^{* \star *} p \leq 0.001$. 

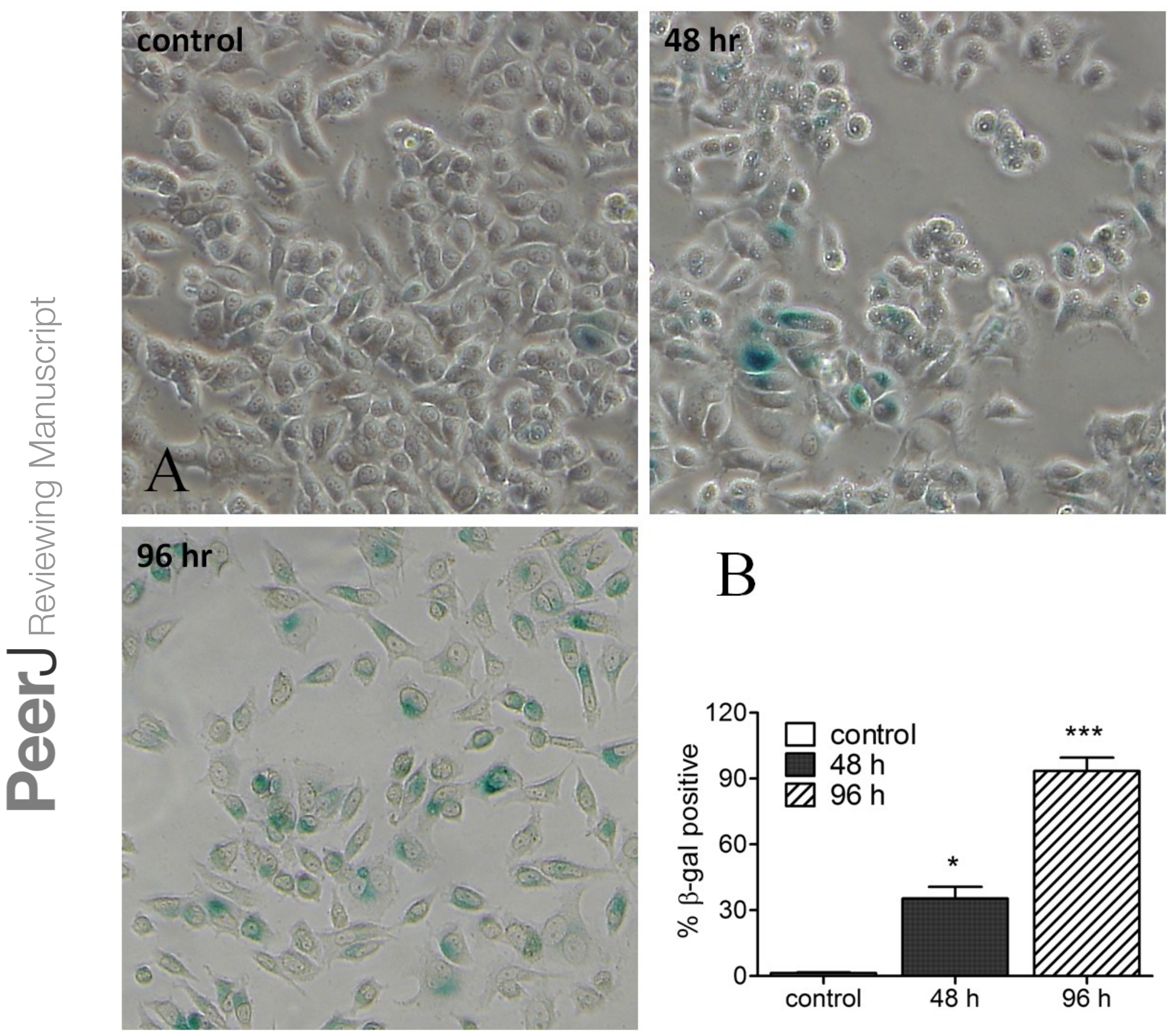


\section{Figure 3}

Effect of harmine on telomerase activity in MCF-7 cells

(A) MCF-7 cells were incubated with harmine at two concentrations $(10 \mu \mathrm{M}$ and $20 \mu \mathrm{M})$ for 24 h, $48 \mathrm{~h}, 72 \mathrm{~h}$ and $96 \mathrm{~h}$. At the end of incubation, telomerase activity was evaluated by applying TRAP assay; the TRAP products were then separated on a 12\% PAGE gel and their intensity (all bands) was quantified by using ImageJ software and values were plotted in (B): Ctr, vehicle control, black bar; cells treated with $10 \mu \mathrm{M}$ of harmine, white bars; cells treated with $20 \mu \mathrm{M}$ of harmine, dotted bars. Results derived from two independent experiments (mean \pm S.D). $p$ values indicate the significant changes in relative telomerase activity for the sample treated with harmine with respect to the vehicle treated controls. Unpaired t test: ${ }^{*} p$ $<0.05 ;{ }^{* *} p \leq 0.01$. 


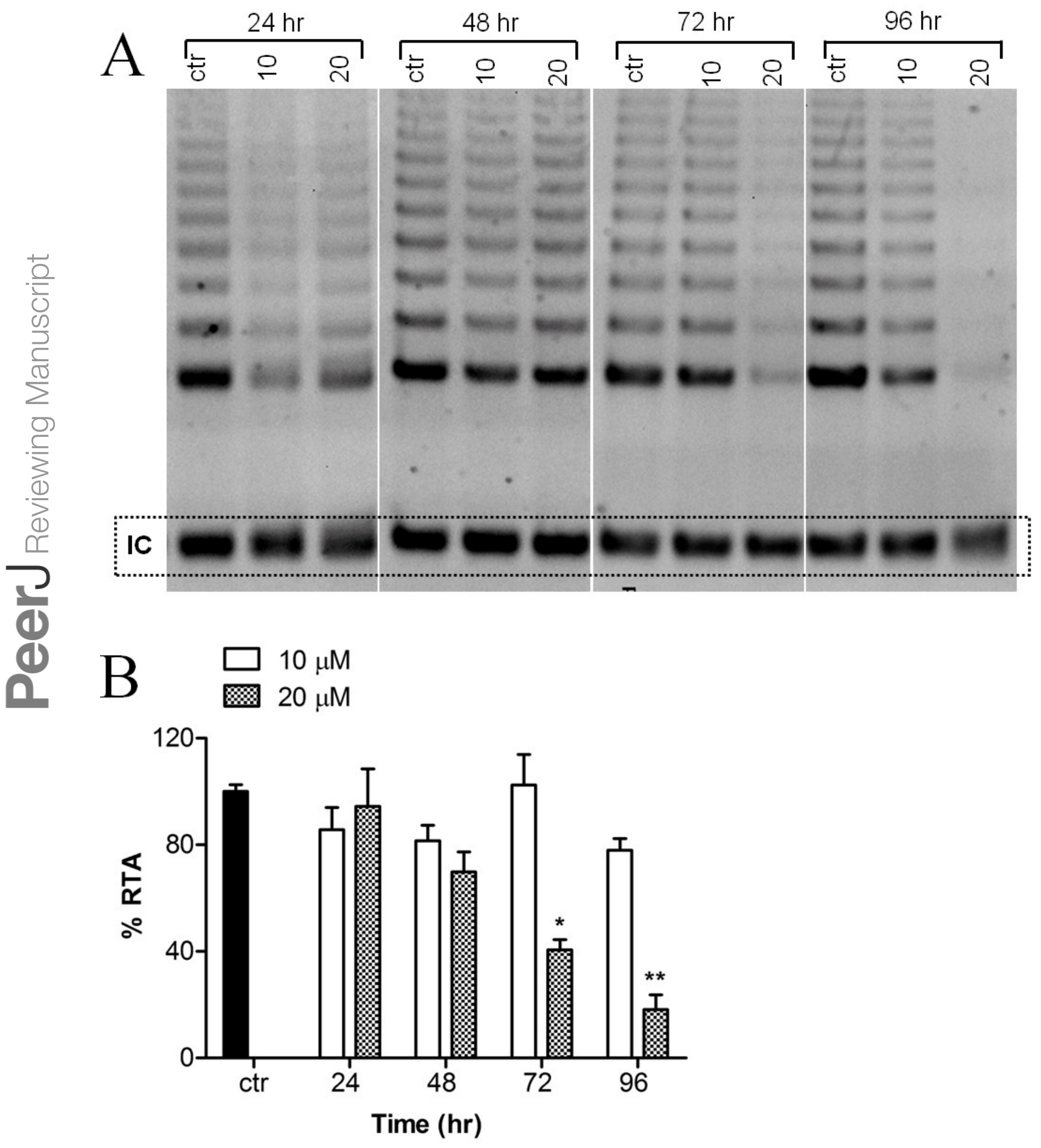




\section{Figure 4}

Harmine inhibits telomerase expression in MCF-7 cells in a dose- and time-dependent manner.

(A) MCF-7 cells were incubated with harmine at final concentration of $10 \mu \mathrm{M}$ and $20 \mu \mathrm{M}$, respectively, then total RNA was isolated and analyzed by using RT-PCR; (B) MCF-7 cells were incubated with harmine at a final concentration of $20 \mu \mathrm{M}$ for $48 \mathrm{~h}$ or $96 \mathrm{~h}$, respectively, then total RNA was isolated and analyzed by RT-PCR.

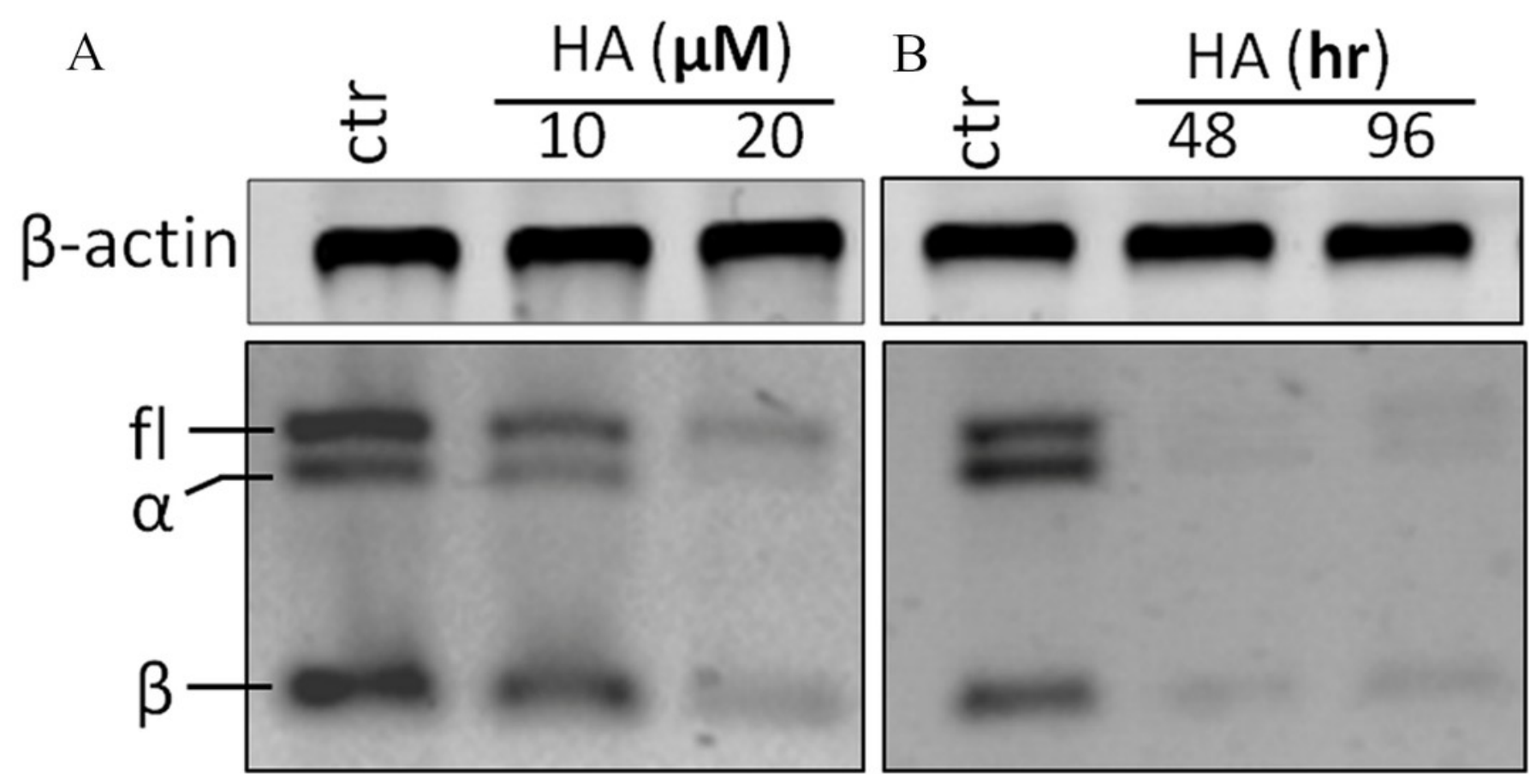




\section{Figure 5}

mRNA levels of hTERT, p21, and CDK2 in response to harmine treatment.

MCF-7 cells were exposed to harmine at a final concentration of $20 \mu \mathrm{M}$ for $12 \mathrm{~h}, 24 \mathrm{~h}, 48 \mathrm{~h}$ and $96 \mathrm{~h}$, then mRNA expression of each target gene was analyzed by real time PCR:

hTERT, white bars; p21, black bars; CDK2, hatched bars. Results are representative of two independent experiments in triplicate (mean $\pm S D$ ). $p$ values measure significant changes in mRNA expression for the target gene treated with harmine with respect to the vehicle treated controls. Unpaired t test: ${ }^{*} p>0.05 ;{ }^{* *} p \leq 0.01 ;{ }^{* *} p \leq 0.001$.

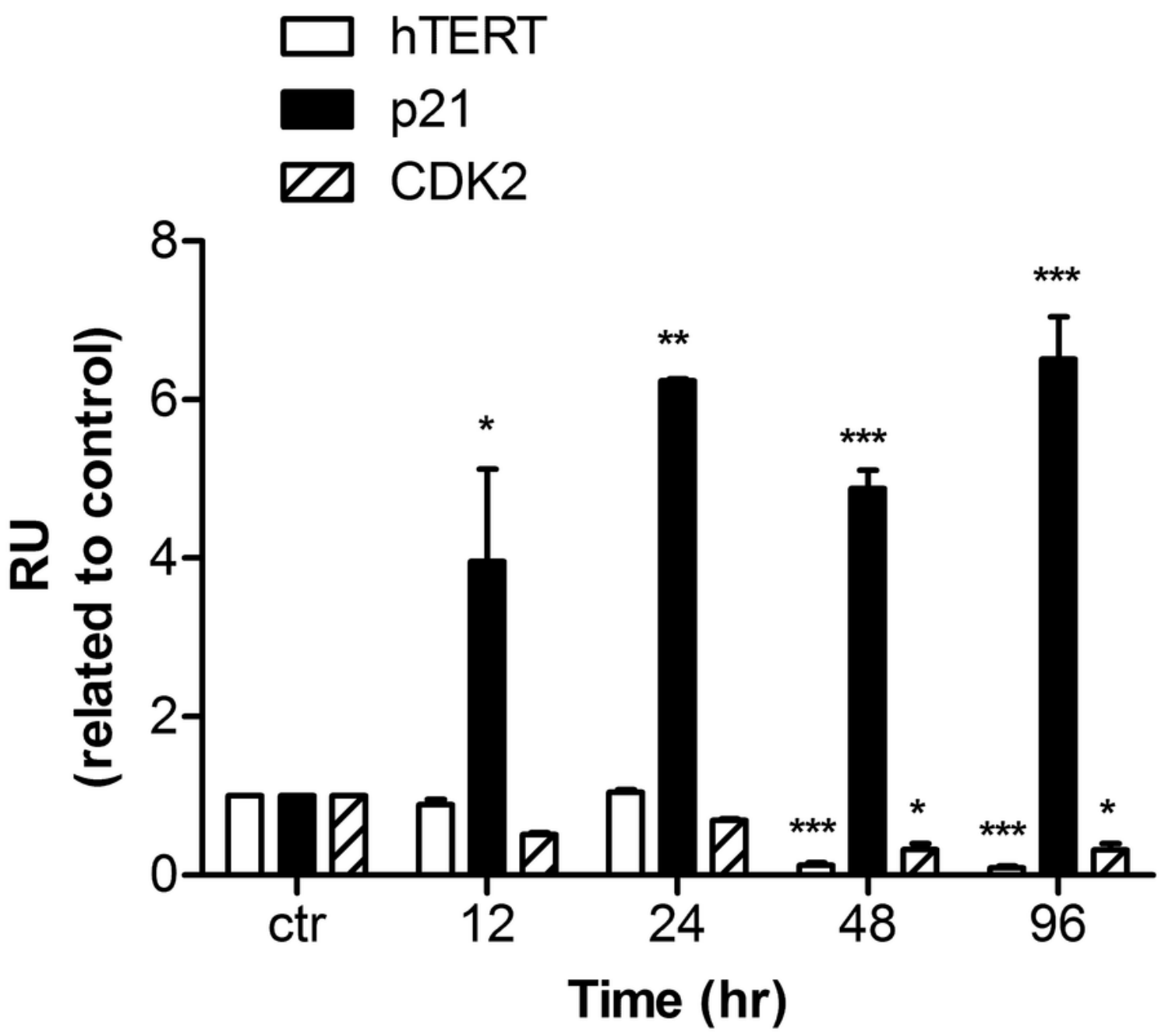




\section{Figure 6}

Harmine induces a general DNA damage response byover-expressing p53/p21 and $\mathrm{ft}$ $2 \mathrm{AX}$.

(A) MCF-7 cells were incubated with harmine at $20 \mu \mathrm{M}$ for $24 \mathrm{~h}, 48 \mathrm{~h}$ and $96 \mathrm{~h}$, then $25 \mu \mathrm{g}$ of total protein extracted from cells after treatment of harmine or vehicle only was separated by PAGE and analyzed by western blotting; $(B)$ changes in protein level after the treatment were calculated with respect to vehicle controls (100\%): p21, black bars; p53, white bars; fy 2 AX, grey bars; c-Myc, hatched bars. 

A

$\operatorname{ctr} \quad \frac{\mathrm{HA} 20 \mu \mathrm{M}(\mathrm{hr})}{24 \quad 48 \quad 96}$

$\beta$-actin

$\mathrm{yH}_{2} \mathrm{AX}$

p53

p21

c-Myc

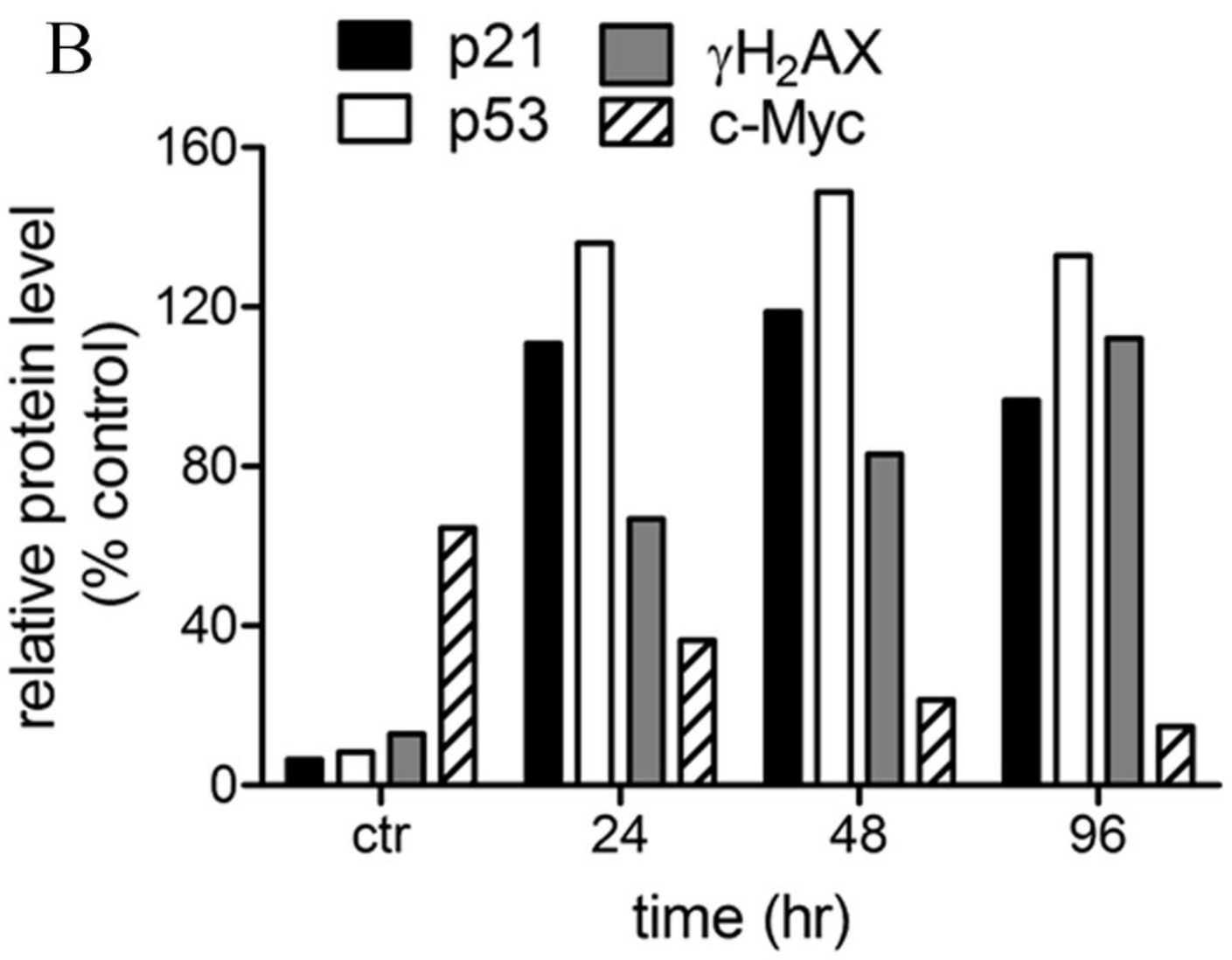

